\title{
Survival of patients with mild angina or myocardial infarction without angina: a comparison of medical and surgical treatment
}

\author{
WILLIAM L PROUDFIT, JOHN R KRAMER, MARLENE GOORMASTIC, \\ FLOYD D LOOP
}

From the Departments of Cardiology, Cardiothoracic Surgery, and Biostatistics, Cleveland Clinic Foundation, Cleveland, Ohio, USA

SUMMARY A group of 390 patients with mild angina pectoris or myocardial infarction without subsequent angina had early coronary bypass operation. Five year survival was significantly higher $(95.4 \%)$ than in a similarly selected medically treated group $(88.5 \%)$ reported before. One death occurred in the 30 day postoperative period. Five year survival in the 179 patients who had internal mammary artery grafts was $98.9 \%$. Survival for patients with mild angina and satisfactory left ventricular function $(96 \cdot 2 \%)$ was significantly higher than in the medical subset $(91 \cdot 3 \%)$.

In the patient population studied, five year survival was higher in patients who had early bypass operations than in those who did not.

The Coronary Artery Surgery Study has influenced selection of patients for coronary bypass surgery. The Coronary Artery Surgery Study randomised trial was confined to patients who had mild angina or myocardial infarction without subsequent angina. ${ }^{1}$ The most unexpected finding was the high survival rate in the medical group ("surgery deferred contingent on worsening symptoms"). A subsequent report of the Coronary Artery Surgery Study "randomisable" patients (eligible for randomisation but not randomised because of decision by the patient or physician) showed similar results for the medical group, although the baseline characteristics of the medical subset differed considerably from those of the medical patients in the randomised study. ${ }^{2}$ In another study of patients in the Coronary Artery Surgery Study registry who were not randomisable, in those with mild angina and satisfactory left ventricular function five year survival of both the medical and surgical patients was $95 \% .^{3}$ Analysis of our medically treated patients selected by the Coronary Artery Surgery Study criteria for the same 46 month entry period showed lower five year survivals than those reported by the Coronary Artery Surgery Study for the whole group and for various subsets."

Requests for reprints to Dr William L Proudfit, Cleveland Clinic Foundation, 9500 Euclid Avenue, Cleveland, OH 44106, USA.

Accepted for publication 24 November 1987
This result suggested that a group of similarly selected surgical patients might also have lower survivals than those reported by the Coronary Artery Surgery Study for surgical patients.

\section{Patients and methods}

The criteria for selection of medical patients were similar to the 18 entry criteria used in the Coronary Artery Surgery Study randomised study, with five minor modifications that were intended to increase clinical specificity. ${ }^{45}$ These entry criteria were used in the present study, except that those patients estimated to have $50-69 \%$ narrowing of the left main coronary artery were included, as in the Coronary Artery Surgery Study. ${ }^{1}$ In our study of medically treated patients, such lesions were grounds for exclusion because it was believed that the expected prognosis was worse than for disease of two or three arteries. An additional deviation was inclusion regardless of geographical residence. The practice of regular five year survival studies of the first 1000 patients who had elective pure coronary bypass surgery each year made 4000 records available for the years 1976-1979. These 4000 patients represent $41.3 \%$ of the patients who had such operations during those years. A computer program was written to match some of the Coronary Artery Surgery Study criteria and 1182 patients were eligible for review. 
Table 1 Baseline variables in study groups (\%)

\begin{tabular}{|c|c|c|c|c|c|c|c|c|}
\hline \multirow{2}{*}{$\begin{array}{l}\text { Variable } \\
\text { Patient (No) } \\
\text { Age (yr): } \\
\text { Mean } \\
\text { SD } \\
\text { Male }\end{array}$} & \multicolumn{2}{|c|}{$A$} & \multicolumn{2}{|c|}{$B$} & \multicolumn{2}{|c|}{$C$} & \multicolumn{2}{|c|}{ All } \\
\hline & (301) & $\begin{array}{r}312 \\
54 \\
7 \\
97\end{array}$ & (25) & $\begin{array}{r}25 \\
55 \\
6 \\
100\end{array}$ & (51) & $\begin{array}{r}53 \\
53 \\
9 \\
96\end{array}$ & (377) & $\begin{array}{r}54 \\
7 \\
97\end{array}$ \\
\hline $\begin{array}{l}\text { Angina (Canadian grading): } \\
\text { None } \\
\text { I } \\
\text { II }\end{array}$ & $\begin{array}{r}(0) \\
(198) \\
(114)\end{array}$ & $\begin{array}{r}0 \\
64 \\
37\end{array}$ & $\begin{array}{r}(0) \\
(16) \\
(9)\end{array}$ & $\begin{array}{r}0 \\
64 \\
36\end{array}$ & $\begin{array}{r}(53) \\
(0) \\
(0)\end{array}$ & $\begin{array}{r}100 \\
0 \\
0\end{array}$ & $\begin{array}{r}(53) \\
(214) \\
(123)\end{array}$ & $\begin{array}{l}14 \\
55 \\
32\end{array}$ \\
\hline $\begin{array}{l}\text { Cigarette use: } \\
\text { Present smoker } \\
\text { Non-smoker } \\
\text { Unknown }\end{array}$ & $\begin{array}{r}(160) \\
(139) \\
(13)\end{array}$ & $\begin{array}{r}51 \\
45 \\
4\end{array}$ & $\begin{array}{r}(10) \\
(13) \\
(2)\end{array}$ & $\begin{array}{r}40 \\
52 \\
8\end{array}$ & $\begin{array}{r}(19) \\
(30) \\
(4)\end{array}$ & $\begin{array}{r}36 \\
57 \\
8\end{array}$ & $\begin{array}{r}(189) \\
(182) \\
(19)\end{array}$ & $\begin{array}{r}49 \\
47 \\
5\end{array}$ \\
\hline $\begin{array}{l}\text { Reported history of: } \\
\text { Hypertension } \\
\text { Previous MI } \\
\text { Heart disease in family } \\
\text { Congestive failure } \\
\text { Diabetes mellitus } \\
\text { Stroke } \\
\text { ASO }\end{array}$ & $\begin{array}{r}(102) \\
(110) \\
(188) \\
(3) \\
(17) \\
(1) \\
(35)\end{array}$ & $\begin{array}{r}33 \\
35 \\
60 \\
1 \\
6 \\
0 \\
11\end{array}$ & $\begin{array}{r}(9) \\
(16) \\
(11) \\
(1) \\
(1) \\
(0) \\
(1)\end{array}$ & $\begin{array}{r}38 \\
64 \\
44 \\
4 \\
4 \\
0 \\
4\end{array}$ & $\begin{array}{r}(14) \\
(53) \\
(28) \\
(3) \\
(3) \\
(1) \\
(5)\end{array}$ & $\begin{array}{r}27 \\
100 \\
53 \\
6 \\
6 \\
2 \\
9\end{array}$ & $\begin{array}{r}(125) \\
(179) \\
(327) \\
(7) \\
(21) \\
(2) \\
(41)\end{array}$ & $\begin{array}{r}32 \\
46 \\
58 \\
2 \\
5 \\
1 \\
11\end{array}$ \\
\hline $\begin{array}{l}\text { Medication at entry: } \\
\text { Nitrites (long-acting) } \\
\beta \text { blocking } \\
\text { Digitalis } \\
\text { Antiarrhythmic } \\
\text { Anticoagulant } \\
\text { Antiplatelet } \\
\text { Thiazides } \\
\text { Other BP medication } \\
\text { Frusemide } \\
\text { Unknown diuretic } \\
\text { Lipid lowering } \\
\text { None of above }\end{array}$ & $\begin{array}{r}(184) \\
(93) \\
(15) \\
(12) \\
(19) \\
(6) \\
(33) \\
(31) \\
(5) \\
(0) \\
(30) \\
(79)\end{array}$ & $\begin{array}{r}59 \\
30 \\
5 \\
4 \\
6 \\
2 \\
11 \\
10 \\
2 \\
0 \\
10 \\
25\end{array}$ & $\begin{array}{l}(15) \\
(8) \\
(3) \\
(1) \\
(1) \\
(0) \\
(7) \\
(2) \\
(0) \\
(0) \\
(4) \\
(4)\end{array}$ & $\begin{array}{r}60 \\
32 \\
12 \\
4 \\
4 \\
0 \\
28 \\
8 \\
0 \\
0 \\
16 \\
160\end{array}$ & $\begin{array}{l}(35) \\
(11) \\
(7) \\
(13) \\
(11) \\
(0) \\
(6) \\
(4) \\
(5) \\
(0) \\
(4) \\
(6)\end{array}$ & $\begin{array}{r}66 \\
21 \\
13 \\
25 \\
21 \\
0 \\
11 \\
8 \\
9 \\
0 \\
8 \\
11\end{array}$ & $\begin{array}{r}(234) \\
(112) \\
(25) \\
(26) \\
(31) \\
(6) \\
(46) \\
(37) \\
(10) \\
(0) \\
(38) \\
(89)\end{array}$ & $\begin{array}{r}60 \\
29 \\
6 \\
7 \\
8 \\
8 \\
2 \\
12 \\
10 \\
3 \\
0 \\
10 \\
23\end{array}$ \\
\hline $\begin{array}{l}\text { Diseased vessels }(\geqslant 70 \% \\
\text { narrowing): } \\
\text { One } \\
\text { Two } \\
\text { Three }\end{array}$ & $\begin{array}{l}(61) \\
(114) \\
(137)\end{array}$ & $\begin{array}{l}20 \\
37 \\
44\end{array}$ & $\begin{array}{r}(3) \\
(6) \\
(10)\end{array}$ & $\begin{array}{l}12 \\
24 \\
64\end{array}$ & $\begin{array}{l}(7) \\
(24) \\
(22)\end{array}$ & $\begin{array}{l}13 \\
45 \\
42\end{array}$ & $\begin{array}{l}(71) \\
(144) \\
(175)\end{array}$ & $\begin{array}{l}18 \\
37 \\
45\end{array}$ \\
\hline $\begin{array}{l}\text { Diseased vessels ( } \geqslant 50 \% \\
\text { narrowing): } \\
\text { Single } \\
\text { Double } \\
\text { Triple }\end{array}$ & $\begin{array}{r}(31) \\
(90) \\
(191)\end{array}$ & $\begin{array}{l}10 \\
29 \\
61\end{array}$ & $\begin{array}{r}(1) \\
(4) \\
(20)\end{array}$ & $\begin{array}{r}4 \\
16 \\
80\end{array}$ & $\begin{array}{l}(3) \\
(14) \\
(36)\end{array}$ & $\begin{array}{r}6 \\
26 \\
68\end{array}$ & $\begin{array}{l}(35) \\
(108) \\
(247)\end{array}$ & $\begin{array}{r}9 \\
28 \\
63\end{array}$ \\
\hline $\begin{array}{l}\text { Proximal LAD disease } \\
(\geqslant 70 \% \text { narrowing })\end{array}$ & (117) & 38 & (11) & 44 & (16) & 30 & (144) & 37 \\
\hline $\begin{array}{l}\text { Left ventricular scores: } \\
\text { Patients (No) } \\
\text { Mean } \\
\text { SD } \\
5 \text { (normal) } \\
6 \text { to } 10 \text { (slightly abnormal) } \\
11 \text { to } 15 \text { (abnormal) }\end{array}$ & $\begin{array}{r}(144) \\
(162) \\
(6)\end{array}$ & $\begin{array}{r}312 \\
6 \\
1 \\
46 \\
52 \\
2\end{array}$ & $\begin{array}{r}(0) \\
(19) \\
(6)\end{array}$ & $\begin{array}{r}25 \\
9 \\
2 \\
0 \\
76 \\
24\end{array}$ & $\begin{array}{r}(0) \\
(47) \\
(6)\end{array}$ & $\begin{array}{r}53 \\
8 \\
2 \\
0 \\
89 \\
11\end{array}$ & $\begin{array}{r}(144) \\
(228) \\
(18)\end{array}$ & $\begin{array}{r}390 \\
7 \\
2 \\
37 \\
59 \\
5\end{array}$ \\
\hline $\begin{array}{l}\text { Ejection fraction: } \\
\text { Patients (No) } \\
\text { Mean } \\
\text { SD } \\
\geqslant 0.50 \\
0.35 \text { to } 0.49 \\
<0.35\end{array}$ & $\begin{array}{r}(312) \\
(0) \\
(0)\end{array}$ & $\begin{array}{r}312 \\
71 \\
9 \\
100 \\
0 \\
0\end{array}$ & $\begin{array}{r}(0) \\
(18) \\
(5)\end{array}$ & $\begin{array}{r}23 \\
40 \\
9 \\
0 \\
78 \\
22\end{array}$ & $\begin{array}{r}(43) \\
(8) \\
(2)\end{array}$ & $\begin{array}{r}53 \\
59 \\
12 \\
81 \\
15 \\
4\end{array}$ & $\begin{array}{r}(355) \\
(26) \\
(7)\end{array}$ & $\begin{array}{r}388 \\
67 \\
13 \\
92 \\
7 \\
2\end{array}$ \\
\hline $\begin{array}{l}\text { Systolic BP: } \\
\text { Mean (mm Hg) } \\
\text { SD (mm Hg) } \\
\geqslant 160 \mathrm{~mm} \mathrm{Hg}(7)\end{array}$ & (47) & $\begin{array}{r}138 \\
19 \\
15\end{array}$ & (3) & $\begin{array}{r}133 \\
19 \\
12\end{array}$ & (7) & $\begin{array}{r}130 \\
19 \\
13\end{array}$ & (57) & $\begin{array}{r}136 \\
19 \\
15\end{array}$ \\
\hline
\end{tabular}


Table 1 Baseline variables in study groups (\%) (continued)

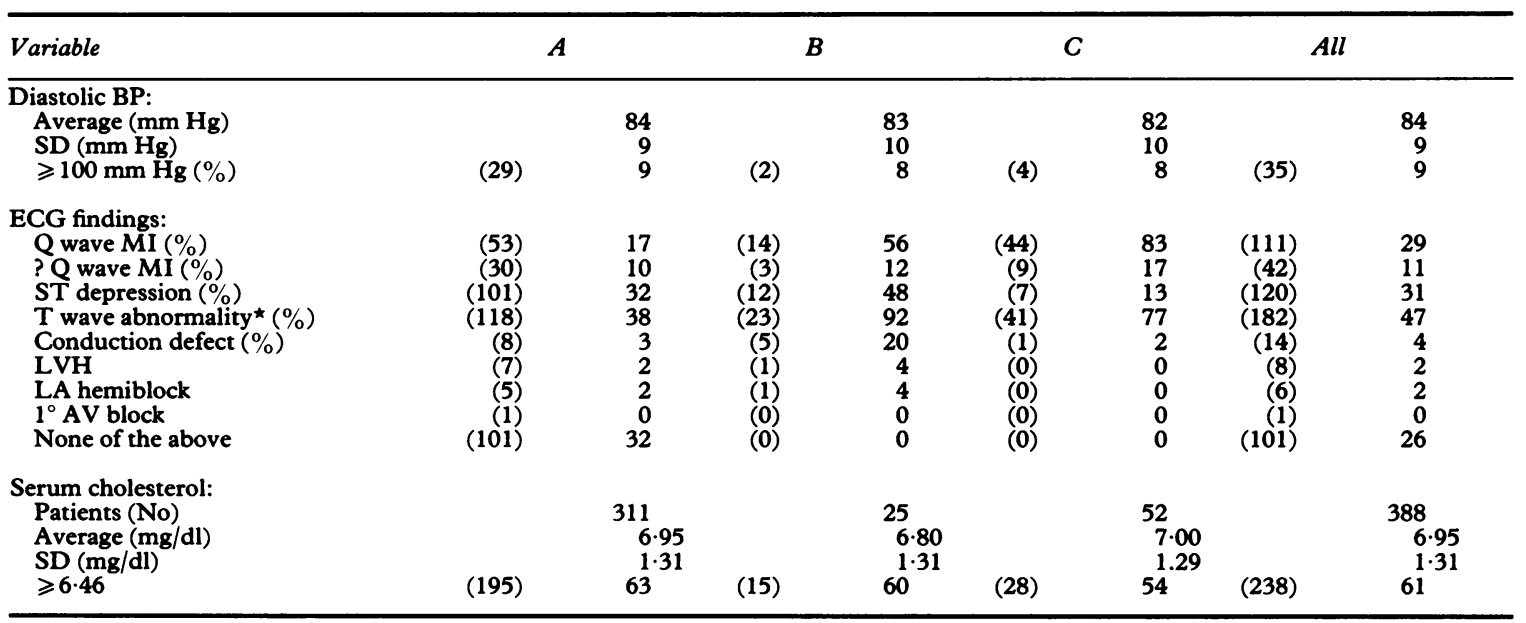

Group A: mild angina and ejection fraction $\geqslant 0.50$.

Group B:mild angina and ejection fraction $<0.50$.

Group C: myocardial infarction without subsequent angina.

$\star$ Diphasic or inverted $T$ waves in leads in which $T$ should be upright.

MI, myocardial infarction; ASO, arteriosclerosis obliterans; LAD, left anterior descending artery; BP, blood pressure;

ECG, electrocardiogram; LVH, left ventricular hypertrophy; LA, left anterior; AV, atrioventricular.

Except where means (SD) are indicated, the numbers in parentheses are the size of the subgroup and the other numbers are percentages to the nearest whole number.

Because we restricted analysis to patients who had catheterisation at the Cleveland Clinic Foundation, 387 patients were excluded. The remaining 795 patient records were reviewed to ensure conformity with the entry criteria. Class 2 angina in our computer coding meant distress that was precipitated by walking one block or more on level ground, but in the Canadian grading system for angina pectoris, used by the Coronary Artery Surgery Study, grade II angina meant either ability to walk at least two blocks before precipitation of distress or conformity with certain other criteria. ${ }^{6}$ Recoding the angina eliminated a large number of patients whose discomfort was too easily precipitated by walking to be classified as Canadian grade II. Additional patients were excluded on the basis of other Coronary Artery Surgery Study criteria and the final study group totalled 390 patients, approximately $15 \%$ of the patients who had pure bypass operations after catheterisation at the Cleveland Clinic Foundation.

Groups A and B in the Coronary Artery Surgery Study both had mild angina and were separated by the ejection fraction, when available. Group A had ejection fraction $\geqslant 0.50$ and group $B<0.50$. Group $\mathrm{C}$ (myocardial infarction without subsequent angina) patients had ejection fraction of at least $0 \cdot 35$.

Ejection fractions were not routinely calculated at the time of catheterisation, so films were reviewed and the ejection fraction was measured without knowledge of clinical or survival information. In two cases the films were not available, so assignment of both to group $B$ was on the basis of the number of areas of the right anterior oblique ventriculogram that showed impairment of contractility, according to the practice used by the Coronary Artery Surgery Study. ${ }^{5}$ Ventricular scoring was done by the Coronary Artery Surgery Study method. A score of 5 was normal, and scores of 6-10 and 11-15 represented mild and moderate left ventricular impairment, respectively. Electrocardiograms were recoded according to the Minnesota criteria, a modification of which was used by the Coronary Artery Surgery Study. ${ }^{7}$

Each patient was followed until death or for a minimum of five years from a date 16 days after catheterisation, because the mean interval between catheterisation and operation was 15.5 days. $^{2}$ No patient who met the criteria for entry into the study died during the 16 day interval or before planned operation. All deaths are included in the statistical analysis.

We used standard life table methods for univariate survival analysis. ${ }^{8}$ Survival curves were compared by the generalised Wilcoxon statistic. ${ }^{9}$ Significance levels of $\mathbf{0 . 0 5}$ or less were considered to be statistically significant. We used the Cox proportional hazard model for multivariate analysis ${ }^{10}$ to test for survival differences in the two groups (medical, surgical). Baseline factors shown ( $a$ ) to differ between the medical and surgical group and $(b)$ to be related to survival were initially forced into the Cox model to 
adjust for any survival differences related to these differences in group characteristics. The difference in survival between the two groups was then tested.

\section{Results}

One of the 390 surgical patients died in the hospital of a transmural myocardial infarction; this was the only death that occurred within 30 days of operation. Definite transmural myocardial infarction was diagnosed postoperatively in eight patients $(2 \cdot 1 \%)$ and questionable transmural infarction in an additional three patients (total of $11(2 \cdot 8 \%)$ ).

In some respects the baseline characteristics of the 390 surgical patients varied considerably from those of the 408 previously reported medical patients (table 1). Group $C$ (myocardial infarction without angina) was smaller in the surgical group than in the medical (53 versus 111 patients), and this accounted for most of the difference in prevalence of myocardial infarction in the two groups. Group $\mathrm{C}$ was small because we are reluctant to advise operations in patients who are symptom free after myocardial infarction. Thiazide treatment was used in $12 \%$ of surgical patients and $20 \%$ of the medical patients. Narrowings of at least $70 \%$ in one, two, and three coronary arteries were found in $18 \%, 37 \%$, and $45 \%$ of the surgical groups, respectively, and $36 \%, 40 \%$, and $25 \%$ of the medical group. The proximal anterior descending artery (before any branches) was more commonly affected in the surgical patients than in the medical patients ( $37 \%$ versus $21 \%$ ). Other baseline characteristics were similar in the medical and surgical groups.

Five year survival of surgical patients was not significantly different for the following subsets: age ( $<50$ and $\geqslant 50$ years), duration of symptoms ( $\leqslant 52$ and $>52$ months), smoking before operation (yes or no), diabetes mellitus (yes or no), arteriosclerosis obliterans (yes or no), systolic hypertension $(<160$ and $\geqslant 160 \mathrm{~mm} \mathrm{Hg}$ ), diastolic hypertension $(<100$ or $\geqslant 100 \mathrm{~mm} \mathrm{Hg}$ ), serum cholesterol $(<6.46$ and $\geqslant 6.46 \mathrm{mmol} / \mathrm{l}$ ), electrocardiogram (normal or abnormal), number of arteries affected (one, two, or three), left main artery $50-69 \%$ narrowed (yes or no), ejection fraction $(<0.50$ and $\geqslant 0.50)$, and clinical group (A, B, and C). Statistically significant differences were found for subsets identified by ventricular score $(5,6-10$, and $11-15 ; p=0.04)$; number of arteries affected in group $A$ patients (one, two, and three; $p=0.05$ ); and internal mammary artery graft (done or not done; $p<0.01$ ). The five year survival of 179 patients who had internal mammary artery grafts as part of their operations was $98.9 \%$, and it was $92 \%$ for those who had saphenous vein grafts only ( $p=0.007$ ). Survival was lower in the eight patients who had perioperative myocardial infarction than those who did not (75 and $96 \% ; p=0.005$ ). The one postoperative death was caused by myocardial infarction; the five year survival of the seven who survived perioperative infarction was not significantly different from those who did not have myocardial infarction $(p=0.25)$.

The figure shows survival curves for surgical patients and for the medical group reported previously. Table 2 compares the five year medical and surgical survivals for the groups and for some subsets. Some of the subsets are small, so statistical comparisons are of doubtful meaning. Five year survival was $85 \%$ for 256 medical patients with multivessel disease and $95 \%$ for 319 surgical patients $(p<0.001)$. For those less than 50 years old medical and surgical survivals were not significantly different, but $44 \%$ of medical patients and $20 \%$ of the surgical group had single vessel disease. Multivessel disease in those aged less than $\mathbf{5 0}$ was associated with survival of $84 \%$ (70 patients) in the medical group and survival of $94 \%$ (78 patients) in the surgical group ( $p=0 \cdot 12)$. Survival of group A patients with multivessel disease was also higher (95\% versus $88 \%$ ) for the surgical group than for the medical group ( $p=0.01$ ).

Table 2 also shows survival of subsets of patients who had internal mammary artery grafts as part of their operation. Survival was higher for those who had internal mammary artery grafts than for the whole surgical group and for various subsets except for patients with single artery disease, all of whom survived. Survival of those patients less than 50 years old with multivessel disease was $100 \%$ if internal mammary artery grafting had been done (41 patients), compared with $84 \%$ (70 patients) for similar medical patients $(p=0.01)$.

We used a Cox model to compare the outcome of medical and surgical treatment, after adjusting for age, number of arteries significantly narrowed, ejec-

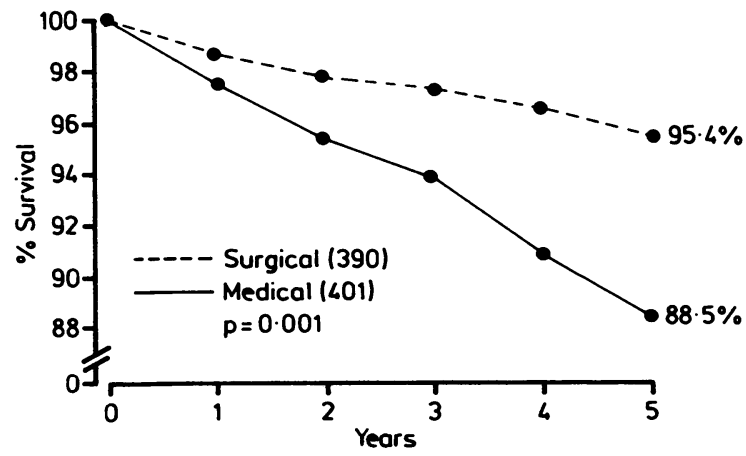

Fig Survival curves of 401 patients treated medically initially and 390 who had early bypass surgery. 
Table 2 Five year survival (\%) of medical and surgical patients

\begin{tabular}{|c|c|c|c|}
\hline \multirow[b]{2}{*}{ Group } & \multirow{2}{*}{$\begin{array}{l}\text { Medical } \\
\text { All Patients }\end{array}$} & \multicolumn{2}{|l|}{ Surgical } \\
\hline & & All Patients & $I M A$ \\
\hline Overall & $89(401)$ & $95(390)[0.001]$ & $99(179)[<0.0001]$ \\
\hline $\begin{array}{l}\text { Age: } \\
\quad<50 \\
\geqslant 50\end{array}$ & $\begin{array}{l}90(125) \\
88(276)\end{array}$ & $\begin{array}{l}95(97)[0.34] \\
96(293)[0.0007]\end{array}$ & $\begin{array}{l}100(51)[0.07] \\
98(128)[0.0005]\end{array}$ \\
\hline $\begin{array}{l}\text { ECG: } \\
\text { Normal } \\
\text { Abnormal }\end{array}$ & $\begin{array}{l}93(101) \\
87(300)\end{array}$ & $\begin{array}{l}98(102)[0.09] \\
94(288)[0.004]\end{array}$ & $\begin{array}{l}98(51)[0 \cdot 20] \\
99(128)[0.0003]\end{array}$ \\
\hline $\begin{array}{l}\text { Number of ves } \\
\text { Single } \\
\text { Double } \\
\text { Triple }\end{array}$ & $\begin{array}{l}95(145) \\
88(159) \\
80(97)\end{array}$ & $\begin{array}{l}100(71)[0 \cdot 14] \\
93(144)[0 \cdot 20] \\
95(175)[0 \cdot 0001]\end{array}$ & $\begin{aligned} 100 & (38)[0.45] \\
98 & (64)[0.01] \\
99 & (77)[0.0002]\end{aligned}$ \\
\hline Proximal AD & $83(82)$ & $95(144)[0.003]$ & 99 (65) [0.002] \\
\hline $\begin{array}{l}\text { Ejection fracti } \\
\quad<50 \\
\geqslant 50\end{array}$ & $\begin{array}{l}79(46) \\
90(353)\end{array}$ & $\begin{array}{l}91 \text { (33) [0.27] } \\
96(355)[0.004]\end{array}$ & $\begin{array}{l}100(9)[0.40] \\
99(168)[0.0002]\end{array}$ \\
\hline $\begin{array}{l}\text { Score: } \\
5 \\
6-10 \\
11-15\end{array}$ & $\begin{array}{l}95(130) \\
86(246) \\
76(25)\end{array}$ & $\begin{array}{l}99(144)[0 \cdot 12] \\
94(228)[0 \cdot 01] \\
89(18)[0 \cdot 33]\end{array}$ & $\begin{array}{c}100(70)[0.07] \\
98(103)[0 \cdot 002] \\
100(6)[0 \cdot 20]\end{array}$ \\
\hline $\begin{array}{c}\text { Group: } \\
\text { A } \\
\text { B } \\
\text { C }\end{array}$ & $\begin{array}{l}91(267) \\
72(25) \\
85(109)\end{array}$ & $\begin{array}{ll}96 & (312)[0.03] \\
88 & (25)[0 \cdot 19] \\
94 & (53)[0 \cdot 19]\end{array}$ & $\begin{array}{c}99(149)[0.003] \\
100(8)[0 \cdot 11] \\
100(22)[0.17]\end{array}$ \\
\hline $\begin{array}{l}\text { Group A: num } \\
\text { Single } \\
\text { Double } \\
\text { Triple }\end{array}$ & $\begin{array}{l}96(111) \\
91(95) \\
85(61)\end{array}$ & $\begin{array}{c}100(61)[0.09] \\
93(114)[0.68] \\
97(137)[0.002]\end{array}$ & $\begin{array}{rr}100 & (35)[0.21] \\
98 & (55)[0.07] \\
98 & (59)[0.01]\end{array}$ \\
\hline
\end{tabular}

IMA, internal mammary artery graft was a part of the surgical technique.

Proximal $A D$, anterior descending coronary artery narrowed $\geqslant 70 \%$ before any branches.

Number of patients are given in parentheses and $\mathrm{p}$ value of medical $v$ surgical comparisons are in square brackets. See methods section for explanation of score.

Ejection fractions are missing in two medical and two surgical patients. See footnote to table 1 for definition of groups A, B, and C.

tion fraction, and electrocardiographic findings including myocardial infarction. There was a significant difference between the two treatment groups in five year survival ( $p=0.0002)$.

Table 3 shows causes of death in the medical and surgical groups. Non-cardiac deaths in the medical group exceeded those in the surgical group, but the difference was not significantly different.

\section{Discussion}

The results of randomised prospective trials are best tested by repetition of the trial. Frequently this approach is practical, but in the case of coronary artery disease with mild angina pectoris or myocardial infarction without angina, repetition is not feasible. We are not questioning the validity of the Coronary Artery Surgery Study trial of treatment of mild angina or myocardial infarction without sub- sequent angina, but rather the clinical applicability of the survival findings. The Coronary Artery Surgery Study group recognised the problem and attempted to provide an answer by studying non-randomised patients in their registry. ${ }^{23}$ Survivals were similar to those of randomised patients. Randomised trials and observational surveys cannot be compared directly even if meticulous attention is paid to duplication of entry criteria in the observational studies. The clinician interprets randomised trials in terms of the patients that he sees rather than as academic exercises, and usually would not apply the 18 entry criteria of the Coronary Artery Surgery Study to his patients. So the results of the trial may not be generally applicable. Because entry criteria can be uniform in an observational survey the results may more closely resemble those of a randomised trial than those of ordinary clinical experience. At least the reproducibility of survival results of nonrandomised patients in the Coronary Artery Surgery 
Table 3 Causes of death ( 5 years)

\begin{tabular}{lllc}
\hline Cause & $\begin{array}{l}\text { Medical } \\
(401)\end{array}$ & $\begin{array}{l}\text { Surgical } \\
(390)\end{array}$ & Total \\
\hline Myocardial infarction & 30 & $9 \star$ & 39 \\
Congestive heart failure & 3 & 1 & 4 \\
Arrhythmia & 1 & 0 & 1 \\
Sudden & 3 & 2 & 5 \\
Non-cardiac & 9 & 4 & 13 \\
Unknown & 0 & 3 & 3 \\
Total & 46 & 19 & 65 \\
\hline
\end{tabular}

^Includes one postoperative death.

Numbers in parentheses are total number of patients followed up five years.

Study may be tested in an independent group of patients.

A study of patients who initially were medically treated, and selected on the basis of the Coronary Artery Surgery Study criteria for randomisation, showed lower survivals for the whole group and most subsets than similar patients of the Coronary Artery Surgery Study. ${ }^{4}$ Lower survival might be caused by some unrecognised baseline variable, and surgical patients might also have lower survival, unless operation negated the influence of the variable. Lower survival after operation would influence the comparison with medical survival. In our comparison of medical and surgical results, survival was higher for surgical patients than for medical patients for the whole group and for all the subsets. The medical and surgical survival curves continue to diverge at five years. Subsets with high ventricular scores or low ejection fractions were small. Restriction of the analysis to patients with multivessel disease and ejection fraction of at least 0.50 , as in the European Coronary Artery Surgery Study, showed significant difference in survival after medical and surgical treatment. ${ }^{11}$ Survival rates for all subsets were higher in patients who had internal mammary artery grafts as part of their operative procedures than for those not stratified by operative procedure; except for patients with single artery disease, all of whom survived. A similar advantage for internal mammary artery grafts has been reported for patients selected on other bases. ${ }^{12}$

The Coronary Artery Surgery Study reported higher survival of surgical patients who had low ejection fractions than that of similar medical patients. ${ }^{1}$ In the present study surgical survival was also higher, but the difference was not significant statistically, perhaps because of the small numbers of patients.

The 390 patients of this survey were selected from 4000 who had coronary bypass operations without additional procedures (valve operation, aneurysmectomy, etc). For many years the first 1000 such patients each year have been followed up every five years. The 4000 patients from the years 1976 to 1979 constituted $41 \%$ of eligible patients from the entire period. All had operation during the first five or six months of the year, but it is likely that they reflect the total experience. The 390 surgical patients in this survey were only a small percentage of the total patients having operation, but this was also true of the Coronary Artery Surgery Study investigation. ${ }^{1}$

This observational study suffers, just as the Coronary Artery Surgery Study "randomisable" study and all other observational studies do, from the questionable comparability of the different treatment groups. We have tried to address this issue by using statistical analyses that adjust for apparent group differences. One can never be sure that all confounding factors have been accounted for. The information gained from the careful analysis of observational data is still of interest and is sometimes the only recourse when a clinical trial is not feasible. In this case, we tried to test the clinical applicability of the results from a randomised prospective trial by matching the criteria for patient selection. Although survival was lower for our medical patients than that reported by the Coronary Artery Surgery Study, surgical survival was similar to that of the Coronary Artery Surgery Study and significantly higher than that of medical patients. The survival of our surgical patients is the same as that of the "randomisable" patients in the Coronary Artery Surgery Study if operative deaths ( 1 in 390 versus 7 in 570, respectively) are excluded. ${ }^{2}$ The reason for the difference in survival of medically treated patients from that reported by the Coronary Artery Surgery Study is not apparent, but if it is ascribed to some unidentified difference in baseline characteristics these must have been nullified by operation. If survival of medically treated patients with mild angina and fairly normal ejection fractions is as high as reported by the Coronary Artery Surgery Study, the wisdom of advising early angioplasty or bypass surgery for improvement in prognosis in patients with mild symptoms might be doubted, unless differences in survival appear later. The lower survivals of our medically treated patients and those in the European Coronary Artery Surgery Study suggest that other studies of patients meeting the Coronary Artery Surgery Study criteria should clarify the clinical applicability of the results of the Coronary Artery Surgery Study. ${ }^{11}$ Improved survival of surgical cases in which internal mammary artery grafting was part of the operative procedure means that future comparisons of medical and surgical treatment should include operative technique as a prognostic variable.

\section{References}

1 CASS Principal Investigators and their Associates. 
Coronary Artery Surgery Study (CASS): a randomized trial of coronary artery bypass surgery: survival data. Circulation 1983;68:939-50.

2 CASS Principal Investigators and their Associates. Coronary Artery Surgery Study (CASS): a randomized trial of coronary artery bypass surgery: comparability of entry characteristics and survival in randomized patients and nonrandomized patients meeting randomization criteria. J Am Coll Cardiol 1984;3:114-28.

3 Kennedy JW, Davis KB, Ryan TJ, Gersh BJ, Fisher LD. Selection of patients for coronary arteriography based on five year CASS survival [Abstract]. Circulation 1985;72 (supp III):385.

4 Proudfit WL, Kramer JR, Bott-Silverman C, Goormastic M. Survival of non-surgical patients with mild angina or myocardial infarction without angina. $\mathrm{Br}$ Heart $J$ 1986;56:213-21.

5 Principal Investigators of CASS and their Associates. The National Heart, Lung, and Blood Institute Coronary Artery Surgery Study (CASS). Circulation 1981;63(suppl II).
6 Campeau L. Grading of angina pectoris. Circulation 1976;54:522-3.

7 Rose GA, Blackburn H. Cardiovascular survey methods. World Health Organization Monograph No. 56. Geneva: World Health Organisation, 1968.

8 Cutler SJ, Ederer F. Maximum utilization of the lifetable method in analyzing survival. $J$ Chronic Dis 1958;8:699-713.

9 Breslow NE. A generalized Kruskal-Wallis test for comparing $\mathrm{K}$ samples subject to unequal pattern of censorship. Biometrika 1970;57:579-94.

10 Cox DR. Regression models and life tables (with discussion). J $R$ Stat Soc (Series B) 1972;34: 187-220.

11 European Coronary Surgery Study Group. Long-term results of prospective randomized study of coronary artery bypass surgery in stable angina pectoris. Lancet 1982;ii:1173-80.

12 Loop FD, Lytle BW, Cosgrove DM, et al. Influence of the internal mammary artery graft on 10-year survival and other cardiac events. N Engl J Med 1986;314:1-6. 